\title{
Circulating LncRNAs Analysis in Patients with Type 2 Diabetes Reveals Novel Genes Influencing Glucose Metabolism and Islet $\beta$-Cell Function
}

\author{
Yuting Ruan Nie Lin Qiang Ma Rongping Chen Zhen Zhang Weiheng Wen \\ Hong Chen Jia Sun
}

Department of Endocrinology, Zhujiang Hospital of Southern Medical University, Guangzhou, P.R. China

\section{Key Words}

LncRNA • Type 2 diabetes $•$ Islet $\bullet \beta$-cell function • Insulin secretion

\begin{abstract}
Background/Aims: The islet is an important endocrine organ to secrete insulin to regulate the metabolism of glucose and maintain the stability of blood glucose. Long noncoding RNAs (IncRNAs) are involved in a variety of biological functions and play key roles in many diseases, including type 2 diabetes (T2D). The aim of this study was to determine whether IncRNA-p3134 is associated with glucose metabolism and insulin signaling in pancreatic $\beta$ cells. Methods: LncRNA microarray technology was used to identify the differentially expressed circulating IncRNAs in T2D patients. RT-PCR analyses were performed to determine the expression of IncRNA-p3134 in 30 pairs of diabetic and non-diabetic patients. The correlation of IncRNA-p3134 to clinical data from T2D patients was analyzed. LncRNA-p3134 was overexpressed in Min6 cells and $\mathrm{db} / \mathrm{db}$ mice by adenovirus-mediated technology. CCK-8, TUNEL, Western blot, glucosestimulated insulin secretion (GSIS), ELISAs and immunochemistry were performed to determine the effect of IncRNA-p3134 on proliferation, apoptosis and insulin secretion both in vitro and vivo. Results: The circulating level of IncRNA-p3134 was higher in diabetic patients than in non-diabetic controls and was correlated with fasting blood glucose and HOMA- $\beta$ levels. The IncRNA-p3134 had risen by 4 times in serum exosomes but nearly unchanged in exosome-free samples. The secretion of IncRNA-p3134 was dynamically modulated by glucose in both Min6 cells and isolated mouse islet cells. LncRNA-p3134 positively regulate GSIS through promoting of key regulators (Pdx-1, MafA, GLUT2 and Tcf7I2) in $\beta$ cells. In addition, the overexpression of IncRNA-p3134 resulted in a decreased apoptosis ratio and partially reversed the glucotoxicity effects on GSIS function in Min6 cells. The restoration of insulin synthesis and secretion the increase of the insulin positive cells areas by upregulation of IncRNA-p3134 in db/db mice confirmed the compensatory role of IncRNA-p3134 to preserve $\beta$-cell function. Furthermore, a protective effect of IncRNA-p3134 on GSIS by positive modulation of PI3K/Akt/mTOR
\end{abstract}

Jia Sun

and Hong Chen

KARGER
Department of Endocrinology, Zhujiang Hospital of Southern Medical University, Guangzhou (P.R. China)

Tel.020-62782333, Fax 020-61643195, E-Mail sunjia@smu.edu.cn, chenhong123@smu.edu.cn 


\section{Cellular Physiology Cell Physiol Biochem 2018;46:335-350

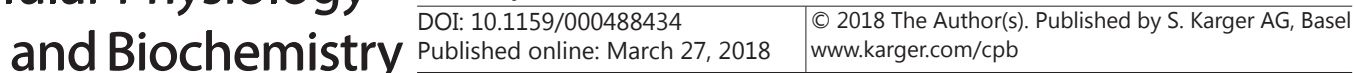 \\ Ruan et al.: LncRNA and Islet B-Cell Function}

signaling was also confirmed. After blocking the PI3K/AKT signals with their specific inhibitor, the effect of overexpressed IncRNA-p3134 on insulin secretion was obviously attenuated. Conclusion: Taken together, the results of this study provide new insights into IncRNA-p3134 regulation in pancreatic $\beta$ cells and provide a better understanding of novel mechanism of glucose homeostasis.

\section{Introduction}

Type 2 diabetes (T2D) results from the loss of glucose homeostasis due to insulin resistance and/or $\beta$-cell dysfunction and involves genetic, environmental, and behavioral components [1-3]. Studies of the pathogenesis of T2D mainly focus on the mechanisms controlling $\beta$-cell adaptation and insulin secretion. This focus is partly due to breakthroughs involving genetic discoveries describing many cases where common genetic variations that are associated with pancreatic $\beta$-cell function increase the risk of T2D. However, protein-coding genes can only explain approximately $10-15 \%$ of T2D cases, suggesting that epigenetics and noncoding sequences are important in the pathophysiology of T2D. Emerging studies have highlighted the importance of noncoding RNA alterations in the pathogenesis of T2D $[4,5]$.

Long noncoding RNAs (lncRNAs) are non-protein-coding transcripts longer than 200 nucleotides [6] that were previously considered "transcription noise", but studies have increasingly demonstrated that IncRNA transcripts are widely involved in almost every aspect of cellular biological functions, such as cell proliferation [7, 8], differentiation [9, 10], metabolism [11], and apoptosis [12]. Accumulating evidence suggests that the aberrant expression of IncRNAs plays an important role in the regulation of pancreatic $\beta$-cell function. The exposure of $\beta$ cells to chronically elevated glucose concentrations has a deleterious impact on their function, leading to defective insulin secretion and, eventually, partial loss of the cells by apoptosis. This combination of events culminates in T2D. For example, the IncRNA HI-LNC25 was identified in isolated islets and shown to regulate the expression of GLIS3, a transcription factor that contains T2D risk variants [13]. KCNQ10T1 is a 91-kb IncRNA localized exclusively in the nucleus. Knocking down the expression of KCNQ10T1 and thereby decreasing the repressive histone modification result in impaired islet proliferation or development. Additionally, the lncRNA KCNQ10T1 was reported to be upregulated in T2D adult islets, which may be part of the compensatory proliferative response to hyperglycemia [14]. Another study indicated that the IncRNA ANRIL was responsible for the age-dependent decline in the capacity for $\beta$-cell proliferation [15]. During the past several years, studies have demonstrated that IncRNAs also exist in various body fluids, such as serum [16], plasma [17], and urine [18]. Circulating lncRNAs may become promising noninvasive biomarkers for assessing the pathophysiological status of various diseases. More notably, circulating IncRNAs could target distant cells or organs and perform a regulatory function in a new location through exosome vesicles [19].

The pancreas is an important endocrine organ. Pancreatic $\beta$ cells secrete insulin to regulate the metabolism of glucose and maintain the stability of blood glucose. It has been found that islet cells can secrete regulatory non-coding RNA [20], but whether circulating IncRNAs has function on target tissue has not been fully clarified yet. Therefore, identification of novel lncRNA for glucose metabolism based upon expression pattern in human circulation and effect on maintenance islet $\beta$-cell function would be very valuable. In this study, we performed an expression profile of IncRNAs and related mRNAs in diabetic patients, with the broader goal of identifying diabetes-affected genes and understanding the pathogenesis of T2D. 


\section{Cellular Physiology Cell Physiol Biochem 2018;46:335-350 \begin{tabular}{l|l} 
and Biochemistry Published online: March 27, 2018 & $\begin{array}{l}\text { C } 2018 \text { The Author(s). Published by S. Karger AG, Basel } \\
\text { www.karger.com/cpb }\end{array}$
\end{tabular} Ruan et al.: LncRNA and Islet B-Cell Function}

\section{Materials and Methods}

\section{Patients}

We consecutively enrolled all consenting adult subjects (18-65 years old) with no past medical history who were seen for a health screening in the Endocrinology Department at Zhujiang Hospital of Southern Medical University (Guangzhou, China) between July 2014 and April 2015. The Research Ethics Committee atZhujiang Hospital of Southern Medical University approved the study protocol (2014-NFMK-005). Written informed consent was obtained from all participants for the use of their blood, and whole blood samples were subsequently collected separately in tubes containing RNA after an overnight fast of 10 to $12 \mathrm{~h}$. The study population consisted of $30 \mathrm{~T} 2 \mathrm{D}$ patients and 30 healthy controls. All patients in the T2D group were diagnosed according to the criteria established by the American Diabetes Association (ADA) [21]. Patients who presented with severe diabetic complications, dyslipidemia, tumors and other diseases in addition to diabetes were excluded from the study. Additionally, individuals who were overweight or obese or who had a family history of diabetes and were on long term medications were also excluded. The 30 healthy subjects in the control group were free from all endocrine diseases. Following a period of overnight fasting, each participant had whole venous blood ( $>3 \mathrm{~mL}$ ) drawn between 7:00 a.m. and 9:00 a.m. Lipid and glucose measurements were obtained using a Siemens Advia 2400 Clinical Chemistry System (Siemens, Germany). The human insulin levels were measured using a human INS ELISA Kit (Minneapolis, USA).

\section{Plasmid construction}

A 743-bp lncRNA-p3134 (ENST00000545923) transcript was amplified and cloned into the GV367 adenovirus vector, which also encodes the enhanced green fluorescent protein (Genechem, China). To prepare adenovirus particles, the adenovirus vector pHelper 1.0 plasmid and the pHelper 2.0 helper plasmid were co-transfected into HEK293T cells according to the manufacturer's recommended protocol. Adenovirus vectors overexpressing IncRNA-p3134 (lncRNA-p3134) and empty negative control (NC) vectors were obtained after virus packaging.

\section{Animal care and islet isolation}

Six-week-old $\mathrm{db} / \mathrm{db}$ female mice and nondiabetic littermate controls ( $\mathrm{db} / \mathrm{m}$ mice) were purchased from the Model Animal Research Center of Nanjing University. The mouse handling and experimental procedures were approved by the Ethics Committee for the Use of Experimental Animals at Southern Medical University. All the animals were raised with access to water and standard mouse chow. Pancreatic islets were isolated as previously described [22]. Briefly, pre-cooled Hank's solution containing $0.5 \mathrm{mg} / \mathrm{L}$ collagenase P was injected into the biliary tract. The pancreas was excised and digested at $37^{\circ} \mathrm{C}$ for $13 \mathrm{~min}$. Islets were obtained using a density gradient and were handpicked. Islets were cultured in 24-well plates with complete RPMI1640 medium (Gibco, USA) containing $11.1 \mathrm{mM}$ glucose and $10 \mathrm{mM}$ HEPES supplemented with 10\% FBS (Biological Industries, Israel), $100 \mathrm{U} / \mathrm{mL}$ penicillin, and $100 \mathrm{mg} / \mathrm{mL}$ streptomycin for $4 \mathrm{~h}$ to recover from the isolation before beginning the following experimental procedures.

\section{Cell culture and adenovirus infection}

The mouse pancreatic $\beta$-cell line Min6 cells were cultured in RPMI 1640 medium at $37^{\circ} \mathrm{C}$ in $5 \% \mathrm{CO}_{2}$. Subcultures were established every three days using trypsin/ethylene diaminetetraacetic acid (EDTA). Before adenovirus infections, the cells were subcultured in a 6-well plate at a density of $4 \times 10^{4} / \mathrm{mL}$. After incubation for $24 \mathrm{~h}$, adenovirus infections were performed at a multiplicity of infection (MOI) of 10 . At $72 \mathrm{~h}$ post-transfection, the expression of EGFP was observed under a fluorescence microscope (Olympus, Japan). Cells were successfully transfected with the LV-IncRNA-p3134 as IncRNA-3134 group and the empty vectors as control, then culture in 6-well plates for $48 \mathrm{~h}$ for future experiments. The islet cells in this study were used between their fourth and sixth passages.

\section{Glucose treatment of Min6 cells and isolated islets}

To study the effect of the glucose exposure, Min6 cells were plated in 6-well plates $\left(5 \times 10^{5}\right.$ per well) and then cultured in DMEM containing 5.5, 11.1, 16.7, 22.2, or $33.3 \mathrm{mM}$ glucose for $24 \mathrm{~h}$ as previously described [23]. After overnight culture in RPMI-1640 medium, the islets were transferred to 12-well plates (100 islets per well) and cultured in $2 \mathrm{~mL}$ RPMI-1640 medium containing 5.5, 11.1, 16.7, 22.2, and $33.3 \mathrm{mM}$ 


\section{Cellular Physiology Cell Physiol Biochem 2018;46:335-350 \begin{tabular}{l|l|l} 
and Biochemistry 10.1159/000488434 & $\begin{array}{l}\text { Dublished online:March 27, } 2018 \\
\text { www.karger.com/cpb }\end{array}$ \\
\hline
\end{tabular} \\ Ruan et al.: LncRNA and Islet B-Cell Function}

glucose for $24 \mathrm{~h}$. At the end of the incubation period, the medium in Min6 cells or isolated islet cell were harvested to measure the IncRNA-p3134 expression.

\section{RNA extraction and real-time PCR analyses}

Total RNA was extracted from the blood samples of all fasted participants using TRIpure LS (Bioteke, China) according to the manufacture's protocol and then stored at $-80^{\circ} \mathrm{C}$ for future analysis. Total Exosome Isolation Reagent was from Invitrogen (Carlsbad, USA). The total RNA from Min6 cells or isolated mouse islets (100 islets form each batch) was isolated using TRIzol (Invitrogen, USA) and reverse-transcribed into cDNA using a Reverse Transcription Kit (Takara, China). Real-time PCR was performed using an ABI Prism 7500 sequence detection system (Applied Biosystems, USA). Each reaction (20 $\mu \mathrm{L}$ ) contained $2 \mu \mathrm{L}$ of cDNA template, $10 \mu \mathrm{L}$ of SYBR Green Master Mix (Takara, Dalian, China), $0.4 \mu \mathrm{L}$ of ROX Reference Dye II, $0.8 \mu \mathrm{L}$ of each of forward and reverse primers, and $6 \mu \mathrm{L}$ of RNase-free $\mathrm{dd}_{2} \mathrm{O}$. Additional File 1 shows the sequences of primers used for RT-PCR. The reactions were performed by incubation in a 96-well plate at $95^{\circ} \mathrm{C}$ for $30 \mathrm{~s}$, followed by 40 cycles of $95^{\circ} \mathrm{C}$ for $5 \mathrm{~s}$ and $60^{\circ} \mathrm{C}$ for $34 \mathrm{~s}$. The expression level of the genes was normalized to $\beta$-actin by comparing the cycle threshold $(\mathrm{Ct})$ values. Gene expression was determined by the $2^{-\Delta \Delta c t}$ methodology and then analyzed for statistical significance.

\section{LncRNA microarray profiling}

We performed microarray profiling using Human LncRNA Microarray V4.0 (CapitalBio Corp, China), including 34, 235 mRNAs and 40, 914 lncRNAs. Briefly, we labeled $10 \mu \mathrm{g}$ of the total RNA using the Superscript Plus Direct cDNA labeling system (Invitrogen) followed by hybridization to the chip. We then scanned the microarrays using an Agilent microarray scanner piloted by GenePix Pro 6.0 software (Axon). We imported the scanned images (TIFF format) into the Agilent Feature Extraction software for grid alignment and expression data analysis. Expression data were normalized by quartile normalization and the Robust Multichip Average (RMA) algorithm that was included in the Agilent software. After normalization, we generated probe-level files and mRNA-level files. All gene-level files were imported into Agilent GeneSpring GX software (version 11.5.1) for further analysis. We identified differentially expressed lncRNAs and mRNAs through fold change filtering. The microarray data were selected using threshold values of greater than a 2 -fold change under FDR protection $(\mathrm{P}<0.05)$.

\section{Bioinformatics analysis}

Differentially regulated mRNAs were uploaded into the Database for Annotation, Visualization and Integrated Discovery (DAVID) for annotation and functional analysis [24], including gene set enrichment analysis and mapping gene sets to the Kyoto Encyclopedia of Genes and Genomes (KEGG) pathway database to analyze the potential functions of IncRNA-p3134 in the pathways [25]. To associate the IncRNAs with directly regulated expression of target mRNAs, we superimposed IncRNA target predictions onto the IncRNA-mRNA correlation network [26]. For each pair of analyzed genes, the Pearson correlation was calculated, and we chose those pairs with significant correlations ( 0.94 or greater) to construct the network using Cytoscape. In this representation, each gene corresponds to a node, and the connection of two genes is represented by an edge, indicating a strong correlation (i.e., either positive or negative).

\section{Cell Counting Kit-8 (CCK-8) assays}

The effect of lncRNA on cell proliferation was analyzed using CCK-8 assays. Min6 cells with and without transfection were seeded at $1 \times 10^{4}$ cells per well in 24-well culture plates with three replicates per condition. At the time points $0,24,48$ and $72 \mathrm{~h}, 20 \mu \mathrm{L}$ CCK-8 solution (Dojindo, Japan) was added to each well for $4 \mathrm{~h}$ at $37^{\circ} \mathrm{C}$. The absorbance was measured at $450 \mathrm{~nm}$ on a microplate reader.

\section{Flow cytometry analysis}

Min6 cells were harvested at $24 \mathrm{~h}$ post-transfection by trypsinization. After double-staining with fluorescein isothiocyanate (FITC)-Annexin V and propidium iodide (PI), the transfected cells were analyzed using flow cytometry (FACScan, BD Biosciences, San Jose, CA) via CellQuest software (BD Biosciences). The cells were discriminated into viable cells, dead cells, early apoptotic cells, and apoptotic cells, which were compared to the control-transfected cells for each experiment. 


\section{Cellular Physiology Cell Physiol Biochem 2018;46:335-350

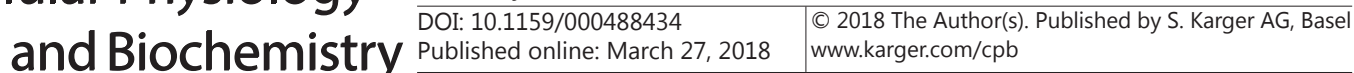 \\ Ruan et al.: LncRNA and Islet B-Cell Function}

Terminal deoxynucleotidyl transferase-mediated dUTP nick-end labeling (TUNEL) assay

TUNEL staining was performed using an EdUTP TUNEL cell detection kit according to the manufacturer's instructions. The cells were incubated in proteinase $\mathrm{K}$ for $15 \mathrm{~min}$ at room temperature, treated without or with $100 \mu \mathrm{M}$ resveratrol, fixed in $4 \%$ paraformaldehyde, and permeabilized with $0.1 \%$ Triton X-100. After washing twice with PBS, the sections were labeled $\left(60 \mathrm{~min}\right.$ and $\left.37^{\circ} \mathrm{C}\right)$ with a fluorescein-TUNEL reagent mixture and observed under a fluorescence microscope (Olympus, Japan) at 488-nm excitation and 530$\mathrm{nm}$ emission, and representative images were captured using a camera. The nuclei were stained using 4',6-diamidino-2-phenylindole (DAPI). The observations revealed the number of apoptotic nuclei and the total number of cells in each high magnification $(\times 400)$ view, with the addition of 4 high magnification views of each section. The apoptotic index (AI) refers to the number of apoptotic nuclei among 100 nuclei. The average value was converted to the AI using the following formula: $\mathrm{AI}=$ number of positive cells/total cells $\times 100 \%$.

Western blot analysis

Min6 cells and isolated mouse islets were lysed using RIPA protein extraction reagent (Beyotime, Beijing, China) supplemented with a protease inhibitor cocktail (Roche, CA) and phenylmethylsulfonyl

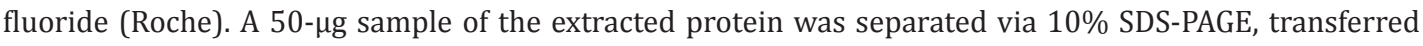
to an Imobilon $®-P$ Transfer membrane (Millipore, USA) and incubated with specific antibodies. The autoradiograms were quantified using densitometry (Quantity One software; Bio-Rad). With the protein content determined, Western blotting was performed. The specific antibodies and dilutions were as follows: anti-caspase3 (1:1000), anti-caspase9 (1:1000), anti-Bcl2 (1:2000), anti-Pdx-1 (1:3000), anti-MafA (1:200), anti-GLUT2 (1:10000), anti-transcription factor 7-like 2 (TCF7L2; 1:10000), anti-PI3K (1:1000), anti-AKT (1:500), anti-pan-AKT (1:1000), and anti-mTOR (1:5000). All antibodies were obtained from ABCAM (AB, USA). The target protein levels were normalized to anti-beta-actin $(1: 10,000)$ from ABCAM (AB, USA). The secondary antibodies used were horseradish peroxidase-conjugated goat anti-rabbit IgG $(1: 10,000)$ and goat anti-mouse IgG (1:5000) from Boster (Boster, China).

Measurement of glucose-stimulated insulin secretion (GSIS) and intracellular insulin protein content

Before stimulation, when the cells reached approximately $70 \%$ confluence, Min6 cells were washed twice with PBS $\left(\mathrm{pH} 7.40,37^{\circ} \mathrm{C}\right)$ and pre-incubated in $500 \mu \mathrm{L}$ Krebs-Ringer bicarbonate (KRB) buffer at $37^{\circ} \mathrm{C}$ in a humidified $5 \% \mathrm{CO}_{2}$ atmosphere. After the 1-h pre-incubation, supernatants were removed. Then, the cells were washed once with glucose-free KRBH and subsequently incubated in fresh KRB buffer containing 2.8 and $16.7 \mathrm{mM}$ glucose, respectively, for $1 \mathrm{~h}$ in 24 -well plates. All incubations occurred at $37^{\circ} \mathrm{C}$ and $5 \% \mathrm{CO}_{2}$. The medium was collected and stored at $-80^{\circ} \mathrm{C}$ for ELISA analysis (Mercodia, Sweden) to evaluate insulin secretion. To determine the insulin content, the cells were harvested via trypsinization in a $15-\mathrm{mL}$ centrifuge tube after transfection, and $4 \times 10^{5}$ cells were ultrasonically disrupted in $1 \mathrm{~mL}$ double distilled water. The sonicate was mixed with acid ethanol ( $0.18 \mathrm{M} \mathrm{HCl}$ in $96 \%$ ethanol (vol/vol)) in a 1:3 proportion of sonicate and acid ethanol. The mixed solution was incubated at $4{ }^{\circ} \mathrm{C}$ for $12 \mathrm{~h}$. The acid ethanol extracts were diluted at least 100 times in Calibrator 0 for ELISA analysis.

\section{Adenoviral transfection in vivo by hydrodynamic injection}

To investigate the function of IncRNA-p3134 function in vivo, db/db female mice were randomized for injection with adenovirus vectors overexpressing lncRNA-p3134 (lncRNA-p3134 group) or empty negative control vectors (db/db group). For hydrodynamic injections, $1 \times 10^{10}$ adenovirus was rapidly injected into the lateral tail vein, as previously described [27]. The overexpression efficiency of IncRNA-p3134 in islets was detected by real-time PCR at 7 days after treatment.

Intraperitoneal glucose tolerance tests (IPGTT) and in vivo glucose stimulated insulin secretion (GSIS)

Seven days after the adenovirus injection, intraperitoneal glucose tolerance tests (IPGTT) and in vivo GSIS measurement were conducted in IncRNA-p3134-treated group and the db/db group. Additionally, $\mathrm{db} / \mathrm{m}$ mice were used as the normal control ( $\mathrm{db} / \mathrm{m}$ group, $\mathrm{n}=6$ for each). In brief, after overnight fasting with free access to water, the mice were intraperitoneally injected with a $20 \%$ glucose solution $11 \mathrm{~g} / \mathrm{kg}$ body weight). The glucose concentrations in $2 \mu \mathrm{L}$ total blood from the tail vein at $0,15,30,60,90$, and 120 min were determined using a glucometer (Roche, USA). The serum was collected from eye canthus blood 


\section{Cellular Physiology Cell Physiol Biochem 2018;46:335-350 and Biochemistry \begin{tabular}{l|l} 
DOI: 10.1159/000488434 & (c) 2018 The Author(s). Published by S. Karger AG, Basel \\
www.karger.com/cpb
\end{tabular} Ruan et al.: LncRNA and Islet B-Cell Function}

at 0 and $30 \mathrm{~min}$, and the insulin concentrations were determined by mouse insulin ELISA kit (Mercodia, Sweden) according to the manufacturer's instructions.

\section{Immunohistochemistry and analysis}

Pancreas tissues were collected and fixed in 4\% paraformaldehyde (PFA) for $24 \mathrm{~h}$. The tissue was then processed and embedded in paraffin, and 5 - $\mu \mathrm{m}$-thick sections were sliced and mounted on glass slides. The mass of beta cells (insulin positive) were stained using the immunoperoxidase technique. After overnight incubation with an anti-insulin primary antibody (Sigma-Aldrich, dilution in 1:500), the HRP-Polymer antiMouse IHC kit (Maixin Bio, China) was applied according to the manufacturer's instructions. Finally, insulinpositive cells were stained with 3, 3-diaminobenzidine (DAB) (Maixin Bio, China) to a golden-brown color and then counterstained with hematoxylin (Maixin Bio). The total areas of the pancreatic tissues and insulinpositive cells were traced manually and those dimensions were analyzed with an image analysis program (AxioVision V4.0, Carl-Zeiss). All the measurements were calculated by analyzing pancreatic tissues from at least 3 mice for each genotype. The ratio of the area of insulin-positive cells to the total area of pancreatic tissue was calculated as previously described [28].

\section{Statistical analysis}

The data were analyzed using SPSS version 22.0 software. Continuous variables are presented as the means $\pm \mathrm{SD}$. The changes in expression for the individual IncRNAs of each subject were calculated relative to the standardized expression levels of the lncRNAs to identify lncRNAs with greater than 2 -fold changes in expression. All statistical comparisons were performed using Student's two-tailed t-test. Differences were considered statistically significant at $\mathrm{p}<0.05$. We also performed correlation analyses for matched data that included the expression levels of IncRNAs and the following variables: body mass index, waist circumference, waist-to-hip ratio, fasting glucose, fasting insulin, TC, TG, HDL cholesterol and LDL cholesterol.

\section{Results}

LncRNA-p3134 is highly expressed in T2D patients

The global expression levels of circulating IncRNAs and mRNAs in diabetic and non-diabetic participants $(\mathrm{n}=3$ for each) were examined using a Human LncRNA Microarray v4.0 (Arraystar, USA) and then validated in 30 diabetic and 30 nondiabetic participants. Table 1 summarizes the anthropometric and metabolic characteristics of the study participants. The circulating lncRNA expression patterns differed significantly between the 3 diabetic and 3 healthy participants. With a

Table 1. Clinical characteristics of included individuals in cross-sectional studies

\begin{tabular}{lccc}
\hline & $\begin{array}{c}\text { Non-diabetic } \\
(\mathrm{n}=30)\end{array}$ & $\begin{array}{c}\text { T2D } \\
(\mathrm{n}=30)\end{array}$ & $\mathrm{p}$ \\
\hline Age (years) & $48.97 \pm 10.56$ & $42.27 \pm 9.78$ & 0.68 \\
Sex (male/female) & $14 / 16$ & $20 / 10$ & 0.30 \\
BMI (kg/m2) & $22.31 \pm 2.30$ & $25.09 \pm 2.88$ & 0.00 \\
Waist circumference $(\mathrm{cm})$ & $79.85 \pm 7.87$ & $89.02 \pm 8.39$ & 0.00 \\
Waist-hip Ratio & $0.84 \pm 0.06$ & $0.94 \pm 0.06$ & 0.00 \\
Fasting glucose $(\mathrm{mmo} / \mathrm{L})$ & $5.02 \pm 0.47$ & $11.30 \pm 3.65$ & 0.00 \\
Fasting insulin $(\mu \mathrm{U} / \mathrm{mL})$ & $8.30 \pm 5.89$ & $8.68 \pm 4.67$ & 0.78 \\
Fasting C-peptide $(\mathrm{ng} / \mathrm{mL})$ & $1.78 \pm 0.71$ & $2.66 \pm 1.02$ & 0.00 \\
HbA1c & $5.63 \pm 1.22$ & $11.85 \pm 2.31$ & 0.00 \\
HOMA- $\beta(\%)$ & $123.51 \pm 116.45$ & $41.27 \pm 38.15$ & 0.00 \\
HOMA-IR & $1.90 \pm 1.42$ & $3.76 \pm 2.17$ & 0.00 \\
Total cholesterol $(\mathrm{mg} / \mathrm{dL})$ & $4.92 \pm 1.02$ & $5.56 \pm 1.01$ & 0.02 \\
Fasting triglycerides $(\mathrm{mg} / \mathrm{dL})$ & $1.57 \pm 1.33$ & $2.77 \pm 2.38$ & 0.02 \\
HDL cholesterol $(\mathrm{mg} / \mathrm{dL})$ & $1.47 \pm 0.46$ & $1.21 \pm 0.25$ & 0.01 \\
LDL cholesterol $(\mathrm{mg} / \mathrm{dL})$ & $3.14 \pm 0.91$ & $3.70 \pm 0.88$ & 0.02 \\
\hline
\end{tabular}

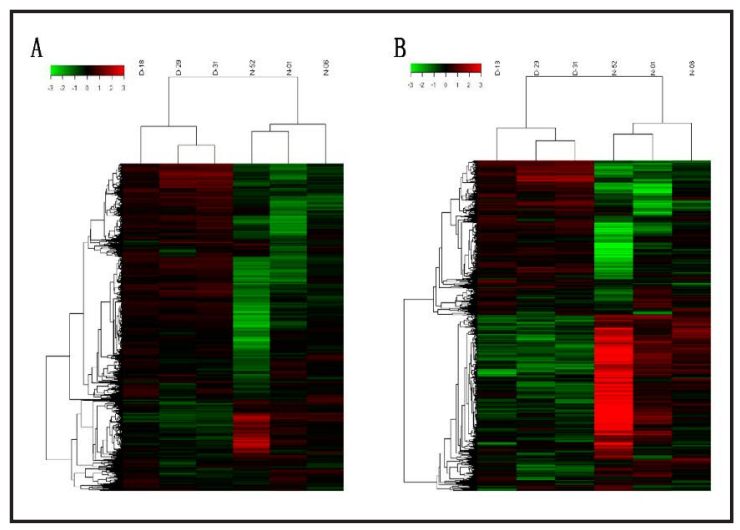

Fig. 1. Expression profiles of differentially expressed IncRNAs and mRNAs in T2D and non-diabetic participants. Differentially expressed lncRNAs and mRNAs between T2D and non-diabetic participants were subjected to hierarchical clustering. The color scale on the top illustrates the relative expression level of IncRNAs across all samples. Red indicates a high relative expression, and green indicates a low relative expression. (A) IncRNA; (B) mRNA. 

Cellular Physiology Cell Physiol Biochem 2018;46:335-350 and Biochemistry \begin{tabular}{l|l} 
DOI: 10.1159/000488434 & $\begin{array}{l}\text { (c) } 2018 \text { The Author(s). Published by S. Karger AG, Basel } \\
\text { www.karger.com/cpb }\end{array}$
\end{tabular}
Ruan et al.: LncRNA and Islet B-Cell Function

2-fold expression difference as the cutoff, $2269 \operatorname{lncRNA}$ transcripts and 2193 mRNA transcripts were specifically dysregulated in T2D participants compared with healthy controls (Fig. 1). Filtering of all dysregulated transcripts for high signal intensity and fold change, lncRNA-p3134 could be consistently dysregulated in a larger cohort of blood samples $\quad(30$ diabetes participants and 30 healthy nondiabetic control participants). We observed a marked increase in the expression of circulating lnc R N A - p 3134 in the diabetic group compared with control group $(\mathrm{p}<0.001$, Fig. 2A). Additionally, the expression of IncRNA-p3134 were positively associated with FBG, fasting Cpeptide, and HOMA-IR levels ( $\mathrm{p}<0.05$ for all) and negatively correlated with HOMA- $\beta$ ( $p=0.00$, Table 2). These results suggest a link between the development of diabetes and the level of circulating IncRNAs.

\section{Exosome package was the main expression pattern of IncRNA-p3134}

Exosome-package is a pattern that secreting lncRNAs to target cells. To find out the resource of circulating IncRNAs, we isolated the exosome from serum samples with or without diabetes. After isolation, samples were analyzed by qRT-PCR for the lncRNA levels. We observed that, the IncRNA levels had risen by 4 times in serum exosomes $(p=0.00$, Fig.

Table 2. Correlation between lncRNAs concentrations and studied variables in the cross-sectional study ${ }^{\text {a }}$ a Data are R (p). NS, not significant

\begin{tabular}{lccccccccc}
\hline & Age & BMI & $\begin{array}{c}\text { Waist to } \\
\text { hip ratio }\end{array}$ & $\begin{array}{c}\text { Fasting } \\
\text { glucose }\end{array}$ & $\begin{array}{c}\text { Fasting } \\
\text { Insulin }\end{array}$ & $\begin{array}{c}\text { Fasting C- } \\
\text { peptide }\end{array}$ & HOMA- $\beta$ & $\begin{array}{c}\text { HOMA- } \\
\text { IR }\end{array}$ & HbA1c \\
\hline IncRNA- & 0.315 & 0.253 & 0.522 & 0.561 & -0.037 & 0.287 & -0.412 & 0.302 & 0.08 \\
p3134 & $(0.01)$ & NS) & $(0.00)$ & $(0.00)$ & (NS) & $(0.03)$ & $(0.00)$ & $(0.02)$ & (NS) \\
\hline
\end{tabular}

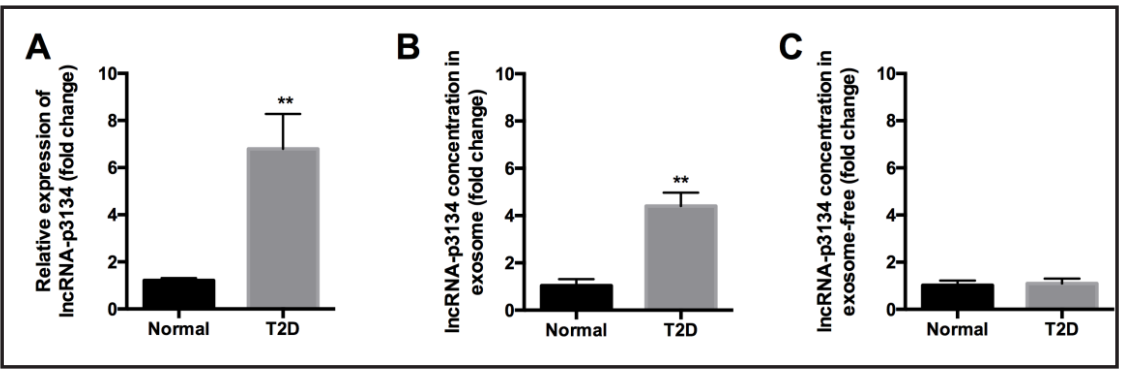

Fig. 2. Expression level of circulating lncRNA-p3134 in exosome or exosome-free in T2D and non-diabetic participants. The expression of lncRNA-p3134 in circulation was determined using qPCR and normalized to the $\beta$-actin expression (A). LncRNA expression in exosomes of serum in patients with or without diabetes (B). LncRNA expression in exosomes-free serum in patients with or without diabetes $(C){ }^{* *}, p<0.01$.

Fig. 3. Secreted and cell expression of IncRNAp3134 in Min6 cells and mouse islets. Secreted lncRNA expression in different glucose concentrations of Min 6 cells culture medium (A) and mouse islets culture medium (B) were determined using RT-PCR and normalized to the $\beta$-actin expression. Medium grown at 11.1 mM concentration served as the control. Cell expresof IncRNA-p3134 in 6 cells (C) and mouse (D) were also de. The values are pre-
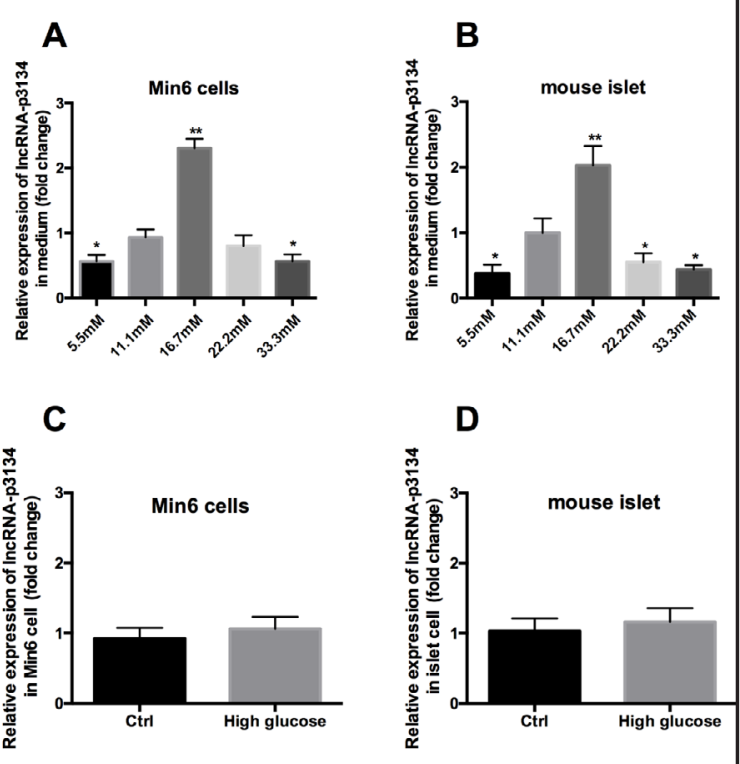
sented as the means $\pm \mathrm{SD}$. ${ }^{*}, \mathrm{p}<0.05 ;{ }^{* *}, \mathrm{p}<0.01$. 


\section{Cellular Physiology Cell Physiol Biochem 2018;46:335-350 \begin{tabular}{l|l} 
DOI: 10.1159/000488434 & and Biochemistry \\
Published online:March 27, 2018 & $\begin{array}{l}\text { 2018 The Author(s). Published by S. Karger AG, Basel } \\
\text { www.karger.com/cpb }\end{array}$
\end{tabular} Ruan et al.: LncRNA and Islet B-Cell Function}

2B), but nearly unchanged in exosome-free samples ( $p=0.67$, Fig. $2 \mathrm{C}$ ) from diabetes patients.

Glucose-dependent regulation of
IncRNA-p3134

The correlation with high IncRNA-p3134 level can either be the cause or consequence of elevated glucose levels. To address this question, we exposed Min6 cells and isolated mouse islets in medium supplemented with different glucose concentrations $(5.5,11.1,16.7,22.2$, and $33.3 \mathrm{mM}$ ) for $24 \mathrm{~h}$. Then we collected the culture medium and extracted RNAs. Medium grown at the standard culture concentration of glucose $(11.1 \mathrm{mM})$ were used as control. We found moderate highlevel glucose can activate islet $\beta$-cell to secrete IncRNA-p3134. LncRNA-p3134 expression to be maximal at $16.7 \mathrm{mM}(\mathrm{p}<$ 0.01 ) and decreased with the higher glucose concentrations in medium culture of Min6 cells $(22.2 \mathrm{mM}$ decreased $13 \%, \mathrm{p}=0.34$; $33.3 \mathrm{mM}$ decreased $37 \%, \mathrm{p}<0.05$, Fig. 3A) and mouse islet cells $(22.2 \mathrm{mM}$ decreased $45 \%, 33.3 \mathrm{mM}$ decreased $57 \%$, $\mathrm{p}<0.05$, Fig. 3B). To find out whether IncRNA-p3134 was secreted actively, selectively or randomly, we detected IncRNA-p3134 level in Min6 cells (Fig. 3C) and islets (Fig. 3D) treated with high-level glucose $(16.7 \mathrm{mM})$. The data showed that there was little change in these situations ( $p>0.05)$. The cell level of IncRNA-p3134 was not consistent with the secretion level, indicating that lncRNA-p3134 was secreted by islet $\beta$ cells treated with high-level glucose, and are selective.

\section{Bioinformatics analysis of IncRNA-coexpressed $m R N A$}

Information regarding lncRNA-p3134 and its co-expressed coding genes may be useful for predicting its functional roles in T2D. KEGG pathway analysis indicated that the IncRNAscoexpressed mRNAs were involved in the regulation of Jak-STAT signaling pathway, insulin signaling pathway, cancer pathways and others (Fig. 4A). We then constructed general lncRNA-mRNA co-expression networks in the T2D group with all the differentially expressed mRNAs from this study. Specifically, the co-expression network of lncRNA-p3134 in the T2D group was composed of 38 mRNAs nodes, including TCF7L2, one of the susceptible genes in individuals with T2D, closely related to glucose-stimulated insulin secretion (Fig. 4B). These data provide a possible link between insulin secretion and lncRNA-p3134 expression.

LncRNA-p3134 increase insulin synthesis and secretion via transcription factors in Min6 cells

To determine whether lncRNA-p3134 participates in regulating insulin secretion, we used lentiviral infections to high-expressed lncRNA-p3134 in Min6 cells. RT-PCR revealed that 
Fig. 5. Overexpression of IncRNAp3134 increased the insulin synthesis and secretion in vitro. Relative expression of IncRNA-p3134 after adenovirus infection was detected by RT-PCR (A). The insulin content was increased in Min6 cells lines after transfection with IncRNAp3134 (B). Insulin secretion stimulated with 2.8 and $16.7 \mathrm{mM}$

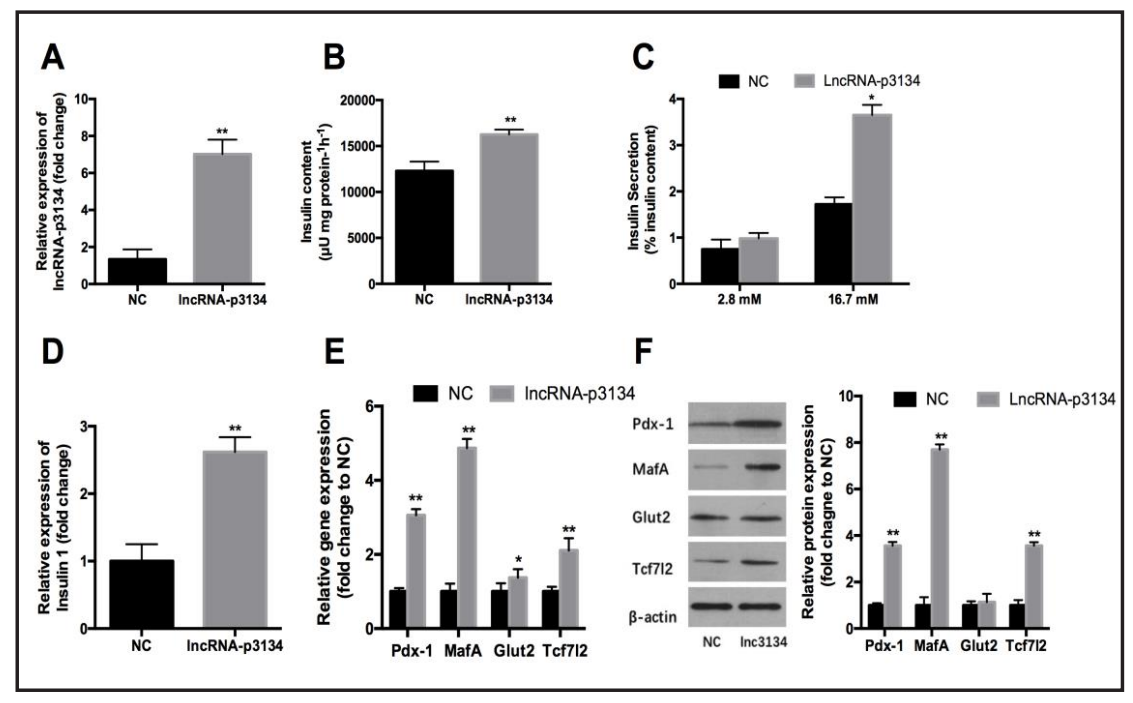
glucose were normal-

ized to the cellular insulin level, and the values are expressed as the percentage of insulin content (C). RTPCR was used to determine the relative expression of insulin 1 (D) and transcription factors involved in $\beta$-cell function, including Pdx-1, MafA, GLUT2, and TCF7L2 (E). The protein levels of transcription factors and genes involved in $\beta$-cell function were analyzed by Western blot (F). $\beta$-actin was used as the internal control. The values are presented as the means \pm SD. ", $p<0.05$; ", $\mathrm{p}<0.01$ versus the NC group.

IncRNA-p3134 expression increased by 6 times compared to empty vector (NC) group ( $\mathrm{p}<$ 0.001 , Fig. 5A). Min6 cells were exposed to $2.8 \mathrm{mmol} / \mathrm{L}$ or $16.7 \mathrm{mmol} / \mathrm{L}$ glucose for a sustained period of $48 \mathrm{~h}$ prior to GSIS assays. Insulin content was increased in the lncRNA-p3134 group ( $p=0.004$, Fig. 5B). The GSIS response of IncRNA-p3134 overexpression in Min6 cells was significantly increased when the glucose concentration was raised from $2.8 \mathrm{mmol} / \mathrm{L}$ to $16.7 \mathrm{mmol} / \mathrm{L}$ compared with that of the control vector group (2.3-fold vs 3.7 -fold, $\mathrm{p}<0.05$, Fig. 5C), supporting our hypothesis that lncRNA-p3134 might have a compensatory effect to preserve pancreatic $\beta$-cell function.

To detect the effects of IncRNA-p3134 on insulin synthesis, we determined insulin 1 mRNA levels in Min6 cells. Real-time RT-PCR analysis revealed lncRNA-p3134 overexpression lead a significant increase of insulin 1 mRNA level ( $p<0.01$, Fig. 5D). Insulin synthesis is regulated by $\beta$-cell-specific transcription factors. We examined both the mRNA and protein levels of selected transcription factors with well-established roles in $\beta$-cell maturation and insulin transcription, including pancreatic and duodenal homeobox factor 1 (Pdx-1), v-maf musculoaponeurotic fibrosarcoma oncogene homologue A (MafA), glucose transporter 2 (GLUT2) and transcription factor 7-like 2 (TCF7L2). RT-PCR analysis of the effects of lncRNA-p3134 showed significantly increased expression of all four transcription factors (Pdx-1, MafA and TCF7L2, P < 0.01; GLUT2, P < 0.05, Fig. 5E) in Min6 cells. LncRNA-p3134 overexpression significantly increased three transcription factors at protein level (Pdx-1, MafA and TCF7L2, $\mathrm{P}<0.01)$, with the greatest effect observed on MafA expression $(7.7 \pm$ 0.23 -fold, Fig. 5F).

Overexpression of IncRNA-p3134 in Min6 cells decreases $\beta$-cell apoptosis

After having established that IncRNA-p3134 promotes insulin synthesis and secretion, we examined the effect of lncRNA-p3134 in maintaining $\beta$-cell mass. We investigated the effects of IncRNA-p3134 upregulation on cell viability and apoptosis in Min6 cells. The CCK8 assay results showed that overexpression of IncRNA-p3134 led to an increased number of viable cells $(1.16 \pm 0.02$ vs. $1.30 \pm 0.04$ at $72 \mathrm{~h}, \mathrm{p}<0.01$, Fig. $6 \mathrm{~A})$. Flow cytometry analysis showed that upregulation of IncRNA-p3134 expression inhibited apoptosis compared to that 
Fig. 6. Effects of IncRNA-p3134 expression on $\beta$-cell proliferation and apoptosis. CCK-8 assays revealed that the Min6 cells proliferation was higher in the IncRNA-p3134 overexpression groups than in the NC groups (A). Min6 cells transfected with IncRNA-p3134 displayed a lower apoptosis ratio, as indicated by flow cytometry (B) and the TUNEL assay (C). A histogram of the apoptotic index (AI) between groups is shown. Western blot analysis of apoptosis-related proteins in $\beta$ cells transfected with IncRNA-p3134 revealed a decrease in the caspase 3 and caspase 9 levels and an increase in the Bcl-2 expression (D). The values are presented as the means \pm SD. ${ }^{*}, \mathrm{p}<0.05 ;{ }^{* *}, \mathrm{p}<0.01$.

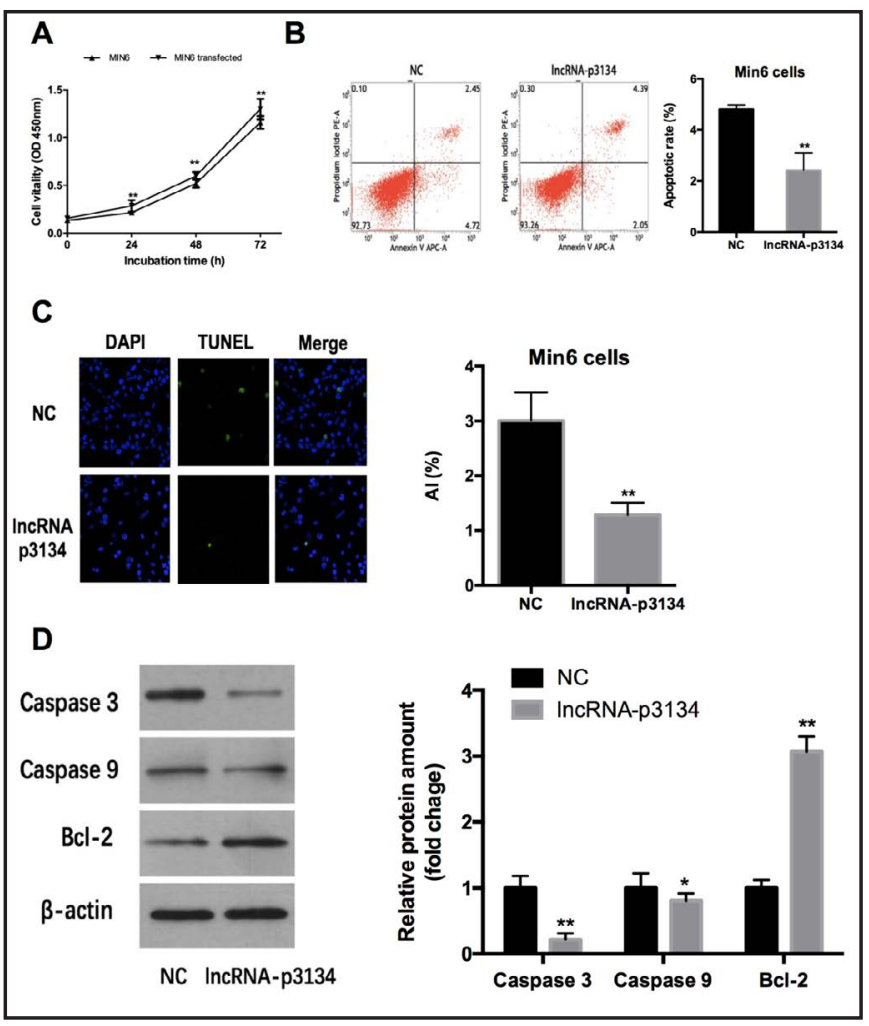

Fig. 7. LncRNA-p3134 protects beta cells from glucotoxicity. Min6 cells were transfected with IncRNA-p3134 or vector control prior to treatment with $33.3 \mathrm{mM}$ glucose concentration for $48 \mathrm{~h}$. TUNEL assay was used to analyze apoptosis ratio of Min6 cells transfected with lncRNA-p3134 (A). A histogram of the apoptotic in$\operatorname{dex}(\mathrm{AI})$ between groups is shown. MafA (B) and Pdx1 (C) mRNA levels were determined by Real-time

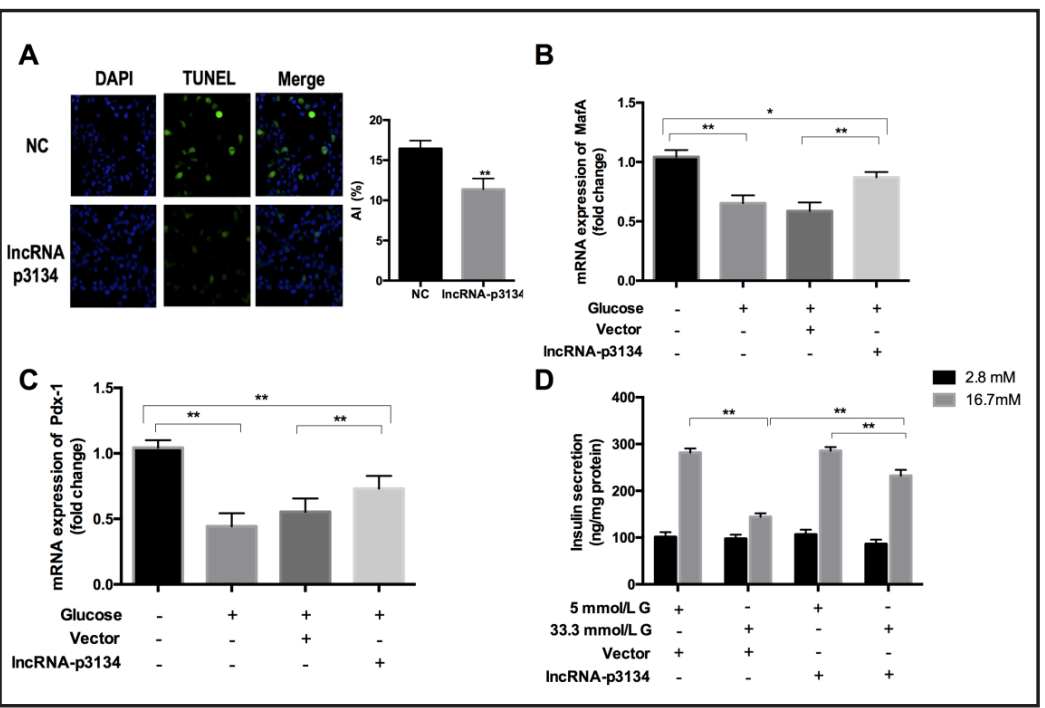
PCR. Serum insulin level were measure by ELISA and GSIS function was calculated (D). ${ }^{*}, \mathrm{p}<0.05$; $^{* *}, \mathrm{p}<0.01$.

in the NC group (control = $4.80 \pm 0.10 \%$; lncRNA-p3134 = 2.41\% $\pm 0.40 \%$; $<$ < 0.01, Fig. 6B). Consistent with our flow cytometry assay findings, the TUNEL staining assay revealed a lower apoptosis ratio in the lncRNA-p3134 group in Min6 cells (Fig. 6C). In addition, we performed Western blot assays to evaluate the expression of apoptotic proteins. Overexpression of lncRNA-p3134 significantly reduced caspase 3 and caspase 9 expression and increased Bcl2 expression in Min6 cells (Fig. 6D). 


\section{Cellular Physiology Cell Physiol Biochem 2018;46:335-350 and Biochemistry \begin{tabular}{c|c} 
DOI: 10.1159/000488434 & P 2018 The Author(s). Published by S. Karger AG, Basel \\
wwww.karger.com/cpb
\end{tabular}

Fig. 8. Upregulaion of $\ln$ cRNA-p3134 in db/db mice affects glucose metabolism. $\mathrm{db} / \mathrm{db}$ mice were injected with IncRNA-p3134 (lncRNA-p3134 group), or negative control vectors $(\mathrm{db} /$ $\mathrm{db}$ group) by intravenous hydrodynamic method. After injection $48 \mathrm{~h}$, pancreas and islets were collected. Islets from nondiabetic littermate controls ( $\mathrm{db} / \mathrm{m}$ group) were used as the normal control. Real-time PCR data were used to determine the lncRNA-p3134 expression levels in pancreas (A) and circulation (B). IPGTT (C) and serum insulin (D) levels
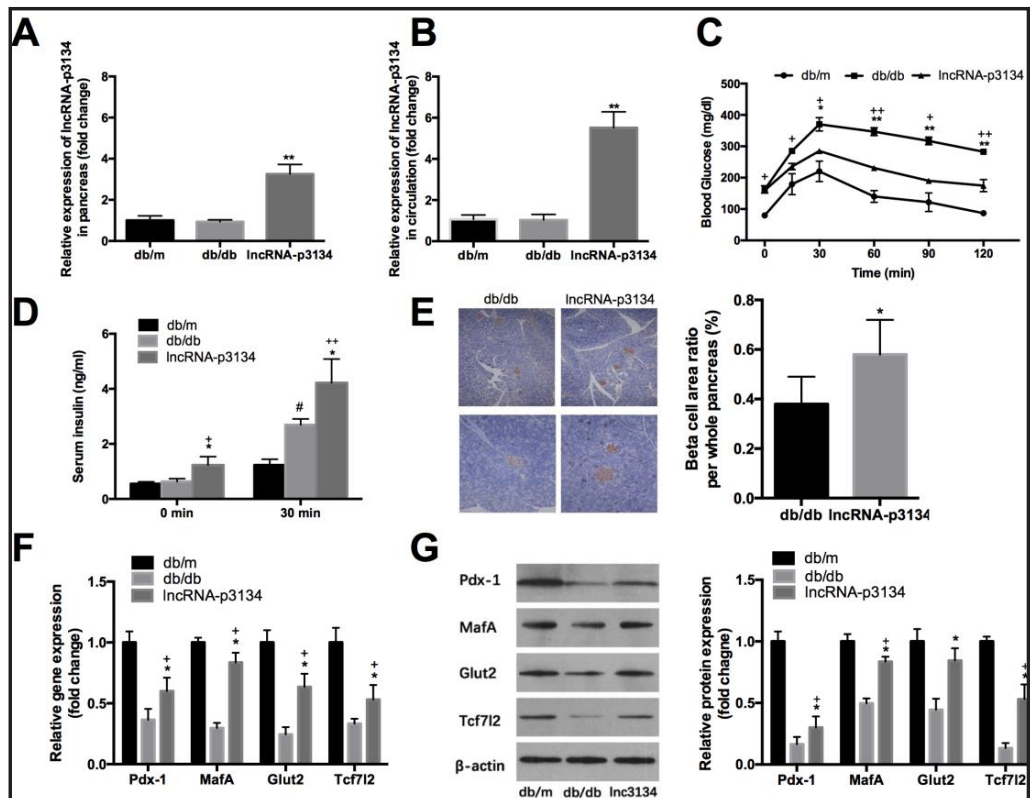

E
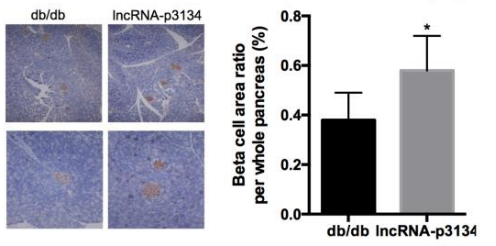

G
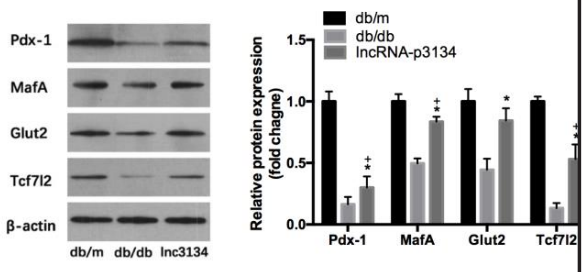

of mice from three groups

were detected ( $n=6$ for each). Pancreatic sections were immunohistochemically stained for insulin. Total areas of pancreatic tissues and insulin-positive cells were traced manually and determined by counting 60 islets or more in six sections per mouse $(n=6)$ in respective groups. The mass of the insulin positive cells was analyzed and results are shown in proportion to the pancreas. Scale bar, 200 and $50 \mathrm{~mm}$ (E). Real-time PCR was used to determine the relative expression of transcription factors and genes involved in $\beta$-cell function (F). The protein levels of transcription factors and genes involved in $\beta$-cell function were analyzed by Western blot (G). $\beta$-actin was used as the internal control. ${ }^{*}, \mathrm{p}<0.05 ;{ }^{* *}, \mathrm{p}<0.01$ versus the db/db group. ${ }^{+}$, $\mathrm{p}<0.05$; $^{++}, \mathrm{p}<0.01$ versus the $\mathrm{db} / \mathrm{m}$ group. ${ }^{*}, \mathrm{p}<0.05, \mathrm{db} / \mathrm{db}$ group versus the $\mathrm{db} / \mathrm{m}$ group.

\section{LncRNA-p3134 protects beta cells from glucotoxicity}

Having observed reduced expression of IncRNA-p3134 in the Min6 cells at $33.3 \mathrm{mM}$ glucose, we wanted to investigate whether lncRNA has a protective effect at this potentially cytotoxic glucose concentration. Min6 cells were transfected with either lncRNA-p3134 or empty vectors and then exposed to $33.3 \mathrm{mM}$ glucose concentration for $48 \mathrm{~h}$. LncRNA-p3134 overexpression in Min6 cells significantly attenuated cell apoptosis by $31.8 \%$ at 33.3 $\mathrm{mM}$ glucose ( $\mathrm{p}=0.013$, Fig. 7A), indicating the cytoprotective effect of IncRNA-p3134 in glucotoxicity state.

Min6 cells were exposed to $5 \mathrm{mmol} / \mathrm{L}$ or $33.3 \mathrm{mmol} / \mathrm{L}$ glucose for a sustained period of $48 \mathrm{~h}$ priors for transcription factors analysis and GSIS assays. In accordance with previous reports, the effects of glucotoxicity showed significantly decreased the expression of transcription factors (MafA, $\mathrm{P}<0.01$; Pdx-1, $\mathrm{P}<0.005)$ in Min6 cells after treatment with $33.3 \mathrm{mmol} / \mathrm{L}$ glucose for $48 \mathrm{~h}$ (Fig. 7B and C). The GSIS response of Min6 cells after exposure to $33.3 \mathrm{mmol} / \mathrm{L}$ glucose was significantly reduced when the glucose concentration was raised from $2.8 \mathrm{mmol} / \mathrm{L}$ to $16.7 \mathrm{mmol} / \mathrm{L}$ compared to that observed after exposure to $5 \mathrm{mmol} / \mathrm{L}$ glucose for $48 \mathrm{~h}(\mathrm{P}<0.001)$. As expected, lncRNA-p3134 overexpression in Min6 cells reversed the high glucose-stimulated decreases in MafA and Pdx-1 expression (MafA, 0.87 \pm 0.03 vs. $0.59 \pm 0.04, p<0.01 ; P d x-1,0.82 \pm 0.03$ vs. $0.58 \pm 0.03, p<0.01$ ). LncRNA-p3134 overexpression also inhibit the effect of glucose-toxicity on GSIS function was alleviated with increased insulin synthesis ( $p<0.01$, Fig. 7D).

Upregulation of IncRNA-p3134 in db/db mice reverse insulin synthesis and secretion

The condition of high glucose concentration exposure to cells cannot fully simulate the diabetic state in vivo. We performed the intravenous hydrodynamic method of transfecting 
IncRNA in $\mathrm{db} / \mathrm{db}$ mice. RT-PCR was used to examine the IncRNA expression in circulation and pancreas seven days after injection. The expression of IncRNA-p3134 was increased by 3.3 times in pancreas and 5.5 times in circulation compared with control $(p<0.01$, Fig. $8 \mathrm{~A}$ and $\mathrm{B}$ ). The fasting blood glucose levels was no significant difference between groups. When challenged by IPGTT, mice overexpressing lncRNA-p 3134 significantly decreased blood glucose levels when compared with $\mathrm{db} /$ $\mathrm{db}$ mice from 30 to
Fig. 9. Overexpression of LncRNA-p3134 positively regulated insulin signaling pathway. The insulin signaling pathway genes were examined using realtime PCR in Min6 cells and pancreatic islets from $\mathrm{db} / \mathrm{db}$ mice (A). The protein expression levels of PI3K, p-AKT, total-AKT and mTOR were analyzed by Western blot (B). In the presence of PI3K inhibitor LY294002, insulin secretion was detected in Min6 cells. (C) $\beta$-actin was used as the internal control. The values are presented as the means $\pm \mathrm{SD} .{ }^{+}, \mathrm{p}<0.05$ versus the NC group of Min6 cells; ", $\mathrm{p}<0.05$ versus the NC group of $d b / d b$

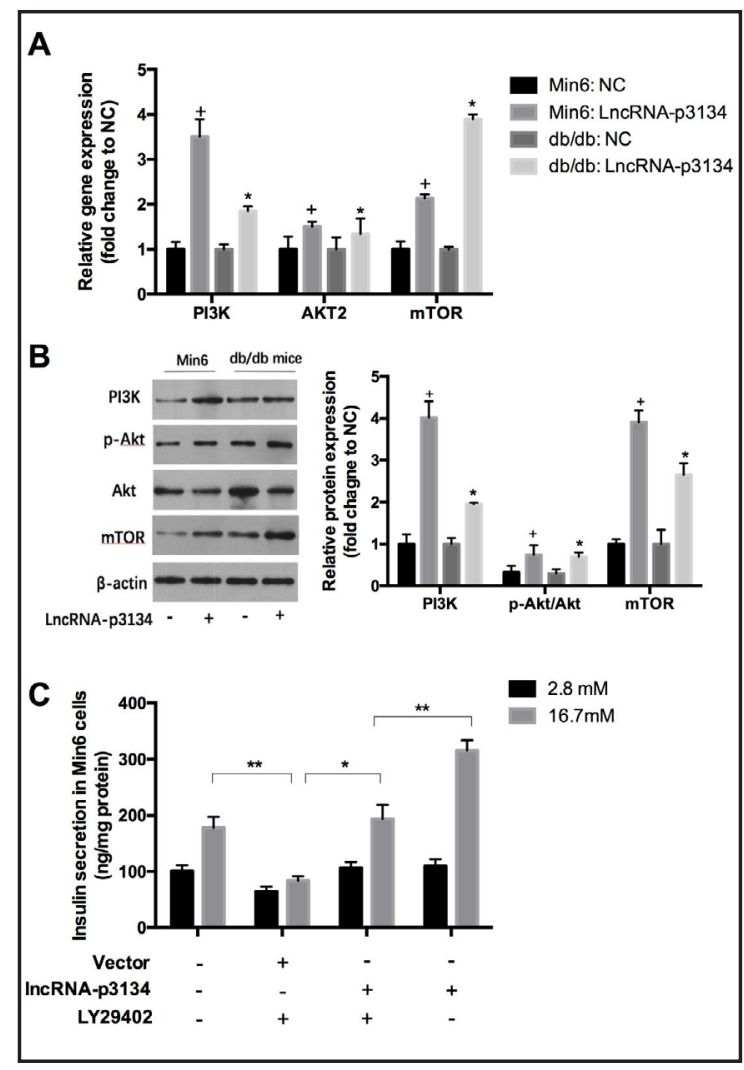
mice, $\mathrm{n}=3 \mathrm{mice} /$ group. $120 \mathrm{~min}$ (ACU glucose level, $675.15 \pm 21$ vs. $464 \pm 13$ vs. $210 \pm 25 \mathrm{mg} / \mathrm{dL} \cdot \mathrm{h}, \mathrm{n}=6$ for each, $p<0.01$, Fig. 8C). Serum insulin levels were higher in IncRNA-p3134 overexpression mice before glucose load and remarkably elevated during GTT at 30 min compared with controls $(4.22 \pm 0.69$ vs. $2.69 \pm 0.12$ vs. $1.23 \pm 0.12 \mathrm{ng} / \mathrm{ml}, \mathrm{p}<0.05$ compared with $\mathrm{db} / \mathrm{db}$ group, $\mathrm{p}<$ 0.01 compared with $\mathrm{db} / \mathrm{m}$ group, Fig. 8D).

The mass of insulin-positive cells detected by insulin immunostaining analysis in $\mathrm{db} /$ $\mathrm{db}$ mice was significantly increased after lncRNA-p3134 upregulated $(0.58 \pm 0.14$ vs. 0.38 $\pm 0.11 \%, p<0.05$, Fig. 8E). Consistent with these findings, islets from the lncRNA-p3134 overexpression mice showed increased mRNA and protein levels of Pdx-1, MafA, GLUT2 and TCF7L2 when compared with $\mathrm{db} / \mathrm{m}$ and $\mathrm{db} / \mathrm{db}$ group, except GLUT2 protein expression compared with $\mathrm{db} / \mathrm{m}$ group (Fig. $8 \mathrm{~F}$ and $\mathrm{G}$ ).

\section{LncRNA-p3134 positively regulated insulin signaling pathway}

The PI3K/Akt/mTOR signaling pathway is closely related to insulin secretion in $\beta$-cells. Bioinformatics analyses also indicated that IncRNA-p3134 regulated GSIS via the insulin signaling pathway, we therefore analyzed the expression of related protein and the activity of the insulin signaling pathway in Min6 cells and $\mathrm{db} / \mathrm{db}$ mice after transfection with IncRNA-p3134. LncRNA-p3134 overexpression significantly elevated the mRNA level of insulin signaling pathway genes, including PI3K, Akt2, and mTOR both in vitro and vivo (Fig. 9A). The protein expression level of PI3K, p-AKT and mTOR was significantly higher after lncRNA-p3134 overexpression in both Min6 cells and db/db mice. AKT phosphorylation increased by $41.47 \pm 12 \%(\mathrm{p}=0.034)$ in Min6 cells and $39.05 \pm 8 \%(\mathrm{p}=0.027)$ in vivo after lncRNA-p3134 overexpression (Fig. 9B). After inhibition of AKT signal using the PI3Kinhibitor LY294002, treatment of Min6 cells with LY294002 attenuated the insulin secretion in $\beta$-cells 


\section{Cellular Physiology Cell Physiol Biochem 2018;46:335-350

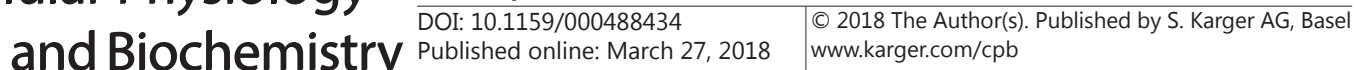 \\ Ruan et al.: LncRNA and Islet B-Cell Function}

compared with lncRNA-p3134 overexpressed group (Fig. 9C). These results indicated the involvement of downstream pathway in IncRNA-p3134 mediated beta cell protection.

\section{Discussion}

Islet $\beta$-cell are endocrine cells with the role of producing insulin and maintaining glucose homeostasis. The central role of pathogenesis in T2D is the defective of $\beta$-cell, presenting in abnormal changes of beta cell mass or deficiency of insulin secretion. Indeed, that defective $\beta$-cell can seed non-coding RNA into bloodstream under pathophysiological conditions is found [29], but whether islet cells can secrete lncRNA has not been clarified yet. LncRNAs can alter the cellular functions by regulating the expression of their target gens and intercellular communication with signaling molecules [30, 31]. Future investigations will be targeted at understanding the function of T2D-specific lncRNAs in maintaining $\beta$-cell function in the development of diabetes [32]. In the present study, we provide a novel lncRNA as a resource for exploring their role in the pathogenesis of T2D. We found the expression of IncRNA-p3134 negatively correlated with HOMA- $\beta$, which is the indicators of beta cell function, suggesting that the increased expression of circulating lncRNA-p3134 might have a potential role in the regulation of $\beta$-cell function. According to the expression profile of human body map, IncRNA-p3134 abundantly expressed in adipose tissue, adrenal, brain, colon, kidney, blood exosome. It also highly expressed in squamous cell carcinoma cell line exosomes, which might be a promising noninvasive biomarker for assessing specific cancer.

We confirmed the most circulating lncRNA-p3134 secreted by islet $\beta$-cell is stored in exosomes. Indeed, a large number of studies have reported that sorts of cells can release lncRNAs-packaged exosomes into circulation. However, whether other tissue contribute to the circulating lncRNA still have to find out. These would be more helpful to understand the regulation to other tissues on $\beta$-cell function. Moreover, islet $\beta$-cell present a transcriptional response to fluctuating concentrations of glucose. Several studies have shown that lncRNAs could be induced or inhibited when exposed to different glucose concentrations [33]. We subsequently detected the intracellular and secretion level of lncRNA-p3134 and verified that lncRNA-p3134 was secreted by islet $\beta$ cells treated with moderate high-level glucose. The upregulated expression pattern with the increasing glucose concentrations is mostly involved in maintaining $\beta$-cell function $[34,35]$. However, this protective effect might be inhibited in response to higher glucose concentrations, as indicated by the negative effects of IncRNA-p3134 during extreme glucotoxicity. These results rule out the possibility that IncRNA-p3134 is changed by islet $\beta$-cell responding strongly to glucose stimulation.

We subsequentlyassessed the potential role of IncRNA-p3134 on the maintenance of insulin synthesis and secretion. The overexpression of lncRNA-p3134 in Min6 cells caused an increase in glucose-stimulated insulin section consistent with upregulation of insulin transcription factors. Studies have revealed that the transcription factors $\mathrm{Pdx}-1$ and MafA coordinately stimulate insulin synthesis by stimulating the insulin gene promoter in response to elevated blood glucose [36]. GLUT2 is a glucose transporter essential for activating glucose-sensitive

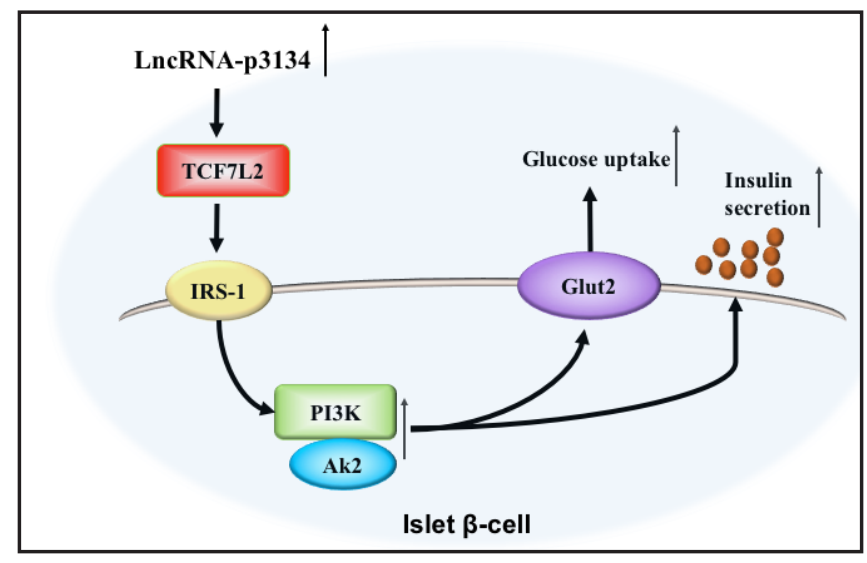

Fig. 10. Possible mechanism of the lncRNA-p3134 regulatory networks in islet $\beta$-cell. The possible ways in which lncRNAp3134 governs the insulin signaling pathway in islet $\beta$-cell. 


\section{Cellular Physiology Cell Physiol Biochem 2018;46:335-350

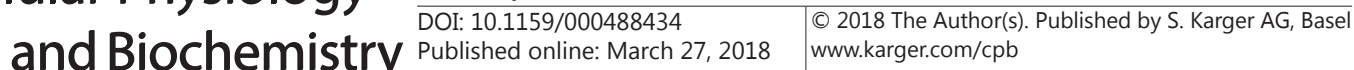 \\ Ruan et al.: LncRNA and Islet B-Cell Function}

genes. Inactivation of GLUT2 may also ultimately lead to impaired GSIS [37]. In our study, we observed that the Pdx-1, MafA and GLUT2 expression levels were upregulated after IncRNA-p3134 overexpression both in vitro and vivo. Additionally, we observed that TCF7L2 expression was increased after IncRNA-p3134 upregulated in Min6 cells and in db/db mice, identify with our bioinformatics analyses. TCF7L2 was mapped to established T2D susceptibility genes [38]. Association studies found that variants of TCF7L2 correlated with impaired GSIS in humans, and selective deletion of TCF7L2 in vitro induced $\beta$-cell apoptosis [39]. Interestingly, overexpression of lncRNA-p3134 in Min6 cells partially reversed the inhibitory effect of glucotoxity on Pdx-1 and MafA expression. As a consequence, the GSIS function were restored. These results clearly implicate lncRNA-p3134 may mediate activation of insulin gene transcription and thus enhance insulin synthesis and secretion.

In addition to promoting insulin secretion, IncRNA-p3134 also led to prevention of apoptosis and maintenance of sufficient $\beta$-cell mass in both normal condition and glucotoxity condition of Min6 cells. However, the vitro experiment cannot fully simulate the diabetic state in vivo. Therefore, we observed whether overexpression of lncRNA-p3134 in db/db mice can reverse the beta cell dysfunction in T2D mouse model. Morphological observation of pancreas tissue in $\mathrm{db} / \mathrm{db}$ mice also verified the effect of lncRNA-p3134 in maintaining $\beta$-cell mass in vivo. Additionally, overexpression of lncRNA-p3134 rescued the glucose tolerance and insulin section challenged by IPGTT in $\mathrm{db} / \mathrm{db}$ mice, supporting our hypothesis that lncRNA-p3134 might have a compensatory effect to preserve pancreatic $\beta$-cell function.

The PI3K/Akt/mTOR signaling pathway is critically involved in glucose metabolism. Activation of PI3K/Akt/mTOR signaling in $\beta$-cell might improve insulin secretion and decrease blood glucose levels by increasing the $\beta$-cell mass [40], as observed in the present study. After blocking the PI3K/AKT signals with their specific inhibitor, the effect of overexpressed lncRNA-p3134 on insulin secretion was obviously attenuated, suggesting that insulin signaling pathway was the potential downstream pathway in lncRNA-p3134 mediated $\beta$-cell protection (Fig. 10). However, the specific mode of regulation between lncRNA-p3134 and insulin signaling pathway remains to be clarified. Although the discovery of the lncRNA-p3134 in the protection effects of high glucose on insulin secretion is of great significance, the direct target molecules regulated by lncRNA-p3134 is needed to study in the future. In addition, due to the notable species differences in IncRNA expression, we failed to perform a knockdown gene study to further elucidate the function of lncRNA-p3134.

\section{Conclusion}

In summary, we provide new insights into the role of IncRNA-p3134 in both T2D patients and pancreatic $\beta$-cell. LncRNA-p3134 secreted by islet $\beta$-cell may be a new signaling molecule that maintain $\beta$-cell mass and enhance insulin synthesis and secretion. Furthermore, lncRNA-p3134 contributed to reverse the deficient of insulin secretion in T2D. It will be of interest to determine whether lncRNA-p3134 produced by other tissues, such as adipose tissue or hepatocytes, can have metabolic effects.

\section{Acknowledgements}

This work was supported by grants to Hong Chen (the National Natural Science Foundation of China no. 81570716, the Natural Science Foundation of Guangdong no. 2016A030313633) and Yuting Ruan (Special Funds for the Cultivation of Guangdong College Students' Scientific and Technological Innovation no. pdjh2017b0104) and Sun Jia (the National Natural Science Foundation of China no. 81670783, the Natural Science Foundation of Guangdong no. 2017A030313473). 


\section{Cellular Physiology Cell Physiol Biochem 2018;46:335-350 and Biochemistry \begin{tabular}{l|l} 
DOI: 10.1159/000488434 & $\begin{array}{l}\text { C } 2018 \text { The Author(s). Published by S. Karger AG, Basel } \\
\text { www.karger.com/cpb }\end{array}$
\end{tabular} Ruan et al.: LncRNA and Islet B-Cell Function}

\section{Disclosure Statement}

No conflict of interests exists.

\section{References}

1 Ashcroft FM, Rorsman P: Diabetes mellitus and the beta cell: the last ten years. Cell 2012;148:1160-1171.

2 Butler AE, Janson J, Bonner-Weir S, Ritzel R, Rizza RA, Butler PC: Beta-cell deficit and increased beta-cell apoptosis in humans with type 2 diabetes. Diabetes 2003;52:102-110.

- Wang X, Chang X, Zhang P, Fan L, Zhou T, Sun K: Aberrant Expression of Long Non-Coding RNAs in Newly Diagnosed Type 2 Diabetes Indicates Potential Roles in Chronic Inflammation and Insulin Resistance. Cell Physiol Biochem 2017;43:2367-2378.

-4 Toperoff G, Aran D, Kark JD, Rosenberg M, Dubnikov T, Nissan B, Wainstein J, Friedlander Y, Levy-Lahad E, Glaser B, Hellman A: Genome-wide survey reveals predisposing diabetes type 2-related DNA methylation variations in human peripheral blood. Hum Mol Genet 2012;21:371-383.

-5 Yang BT, Dayeh TA, Volkov PA, Kirkpatrick CL, Malmgren S, Jing X, Renstrom E, Wollheim CB, Nitert MD, Ling C: Increased DNA methylation and decreased expression of PDX-1 in pancreatic islets from patients with type 2 diabetes. Mol Endocrinol 2012;26:1203-1212.

-6 Kung JT, Colognori D, Lee JT: Long noncoding RNAs: past, present, and future. Genetics 2013;193:651-669.

7 Luo G, Liu D, Huang C, Wang M, Xiao X, Zeng F, Wang L, Jiang G: LncRNA GAS5 Inhibits Cellular Proliferation by Targeting P27(Kip1). Mol Cancer Res 2017;15:789-799.

-8 Jin F, Wang N, Zhu Y, You L, Wang L, De W, Tang W: Downregulation of Long Noncoding RNA Gas5 Affects Cell Cycle and Insulin Secretion in Mouse Pancreatic beta Cells. Cell Physiol Biochem 2017;43:2062-2073.

-9 Alvarez-Dominguez JR, Bai Z, Xu D, Yuan B, Lo KA, Yoon MJ, Lim YC, Knoll M, Slavov N, Chen S, Peng C, Lodish HF, Sun L: De Novo Reconstruction of Adipose Tissue Transcriptomes Reveals Long Non-coding RNA Regulators of Brown Adipocyte Development. Cell Metab 2015;21:764-776.

10 Qi M, Zhou Q, Zeng W, Shen M, Liu X, Luo C, Long J, Chen W, Zhang J, Yan S: Analysis of Long Non-Coding RNA Expression of Lymphatic Endothelial Cells in Response to Type 2 Diabetes. Cell Physiol Biochem 2017;41:466-474.

11 Liu X, Xiao ZD, Han L, Zhang J, Lee SW, Wang W, Lee H, Zhuang L, Chen J, Lin HK, Wang J, Liang H, Gan B: LncRNA NBR2 engages a metabolic checkpoint by regulating AMPK under energy stress. Nat Cell Biol 2016;18:431-442.

12 Lu W, Huang SY, Su L, Zhao BX, Miao JY: Long Noncoding RNA LOC100129973 Suppresses Apoptosis by Targeting miR-4707-5p and miR-4767 in Vascular Endothelial Cells. Sci Rep 2016;6:21620.

13 Moran I, Akerman I, van de Bunt M, Xie R, Benazra M, Nammo T, Arnes L, Nakic N, Garcia-Hurtado J, Rodriguez-Segui S, Pasquali L, Sauty-Colace C, Beucher A, Scharfmann R, van Arensbergen J, Johnson PR, Berry A, Lee C, Harkins T, Gmyr V, Pattou F, Kerr-Conte J, Piemonti L, Berney T, Hanley N, Gloyn AL, Sussel L, Langman L, Brayman KL, Sander M, McCarthy MI, Ravassard P, Ferrer J: Human beta cell transcriptome analysis uncovers lncRNAs that are tissue-specific, dynamically regulated, and abnormally expressed in type 2 diabetes. Cell Metab 2012;16:435-448.

14 Sunamura N, Ohira T, Kataoka M, Inaoka D, Tanabe H, Nakayama Y, Oshimura M, Kugoh H: Regulation of functional KCNQ10T1 IncRNA by beta-catenin. Sci Rep 2016;6:20690.

15 Cunnington MS, Santibanez Koref M, Mayosi BM, Burn J, Keavney B: Chromosome 9p21 SNPs Associated with Multiple Disease Phenotypes Correlate with ANRIL Expression. PLoS Genet 2010;6:e1000899.

16 Shen X, Zhang Y, Wu X, Guo Y, Shi W, Qi J, Cong H, Wang X, Wu X, Ju S: Upregulated lncRNA-PCAT1 is closely related to clinical diagnosis of multiple myeloma as a predictive biomarker in serum. Cancer Biomark 2017;18:257-263.

17 Tan L, Yang Y, Shao Y, Zhang H, Guo J: Plasma lncRNA-GACAT2 is a valuable marker for the screening of gastric cancer. Oncol Lett 2016;12:4845-4849.

18 Terracciano D, Ferro M, Terreri S, Lucarelli G, D’Elia C, Musi G, de Cobelli O, Mirone V, Cimmino A: Urinary long noncoding RNAs in nonmuscle-invasive bladder cancer: new architects in cancer prognostic biomarkers. Transl Res 2017;184:108-117.

19 Conigliaro A, Costa V, Lo Dico A, Saieva L, Buccheri S, Dieli F, Manno M, Raccosta S, Mancone C, Tripodi M, De Leo G, Alessandro R: CD90+ liver cancer cells modulate endothelial cell phenotype through the release of exosomes containing H19 lncRNA. Mol Cancer 2015;14:155. 


\section{Cellular Physiology Cell Physiol Biochem 2018;46:335-350 \begin{tabular}{ll|l} 
DOI: 10.1159/000488434 & and Biochemistry & $\begin{array}{l}\text { O 2018 The Author(s). Published by S. Karger AG, Basel } \\
\text { www.karger.com/cpb }\end{array}$ \\
\cline { 2 - 3 }
\end{tabular} \\ Ruan et al.: LncRNA and Islet B-Cell Function}

20 Zhang A, Li D, Liu Y, Li J, Zhang Y, Zhang CY: Islet beta cell: An endocrine cell secreting miRNAs. Biochem Biophys Res Commun 2018;495:1648-1654.

21 Association. AD: Standards of medical care in diabetes-2015 abridged for primary care providers. Clin Diabetes 2015;33:97-111.

-22 Xu G, Chen J, Jing G, Shalev A: Thioredoxin-interacting protein regulates insulin transcription through microRNA-204. Nat Med 2013;19:1141-1146.

-23 Burns SM, Vetere A, Walpita D, Dancik V, Khodier C, Perez J, Clemons PA, Wagner BK, Altshuler D: Highthroughput luminescent reporter of insulin secretion for discovering regulators of pancreatic Beta-cell function. Cell Metab 2015;21:126-137.

24 Dennis G, Jr., Sherman BT, Hosack DA, Yang J, Gao W, Lane HC, Lempicki RA: DAVID: Database for Annotation, Visualization, and Integrated Discovery. Genome Biol 2003;4:P3.

25 Li JP, Liu LH, Li J, Chen Y, Jiang XW, Ouyang YR, Liu YQ, Zhong H, Li H, Xiao T: Microarray expression profile of long noncoding RNAs in human osteosarcoma. Biochem Biophys Res Commun 2013;433:200-206.

26 Yu G, Yao W, Wang J, Ma X, Xiao W, Li H, Xia D, Yang Y, Deng K, Xiao H, Wang B, Guo X, Guan W, Hu Z, Bai Y, Xu H, Liu J, Zhang X, Ye Z: LncRNAs expression signatures of renal clear cell carcinoma revealed by microarray. PLoS One 2012;7:e42377.

27 Zhu M, Wei Y, Geissler C, Abschlag K, Corbalan Campos J, Hristov M, Mollmann J, Lehrke M, Karshovska E, Schober A: Hyperlipidemia-Induced MicroRNA-155-5p Improves beta-Cell Function by Targeting Mafb. Diabetes 2017;66:3072-3084.

28 Terauchi Y, Iwamoto K, Tamemoto H, Komeda K, Ishii C, Kanazawa Y, Asanuma N, Aizawa T, Akanuma Y, Yasuda K, Kodama T, Tobe K, Yazaki Y, Kadowaki T: Development of non-insulin-dependent diabetes mellitus in the double knockout mice with disruption of insulin receptor substrate- 1 and beta cell glucokinase genes. Genetic reconstitution of diabetes as a polygenic disease. J Clin Invest 1997;99:861-866.

-29 Plaisance V, Waeber G, Regazzi R, Abderrahmani A: Role of microRNAs in islet beta-cell compensation and failure during diabetes. J Diabetes Res 2014;2014:618652.

30 Mercer TR, Dinger ME, Mattick JS: Long non-coding RNAs: insights into functions. Nat Rev Genet 2009;10:155-159.

31 Wapinski O, Chang HY: Long noncoding RNAs and human disease. Trends Cell Biol 2011;21:354-361.

-32 Benner C, van der Meulen T, Caceres E, Tigyi K, Donaldson CJ, Huising MO: The transcriptional landscape of mouse beta cells compared to human beta cells reveals notable species differences in long non-coding RNA and protein-coding gene expression. BMC Genomics 2014;15:620.

33 Ding GL, Wang FF, Shu J, Tian S, Jiang Y, Zhang D, Wang N, Luo Q, Zhang Y, Jin F, Leung PC, Sheng JZ, Huang HF: Transgenerational glucose intolerance with Igf2/H19 epigenetic alterations in mouse islet induced by intrauterine hyperglycemia. Diabetes 2012;61:1133-1142.

34 Sabatini PV, Krentz NA, Zarrouki B, Westwell-Roper CY, Nian C, Uy RA, Shapiro AM, Poitout V, Lynn FC: Npas4 is a novel activity-regulated cytoprotective factor in pancreatic beta-cells. Diabetes 2013;62:28082820.

-35 Sathanoori R, Olde B, Erlinge D, Goransson O, Wierup N: Cocaine- and amphetamine-regulated transcript (CART) protects beta cells against glucotoxicity and increases cell proliferation. J Biol Chem 2013;288:3208-3218.

36 Guo QS, Zhu MY, Wang L, Fan XJ, Lu YH, Wang ZW, Zhu SJ, Wang Y, Huang Y: Combined transfection of the three transcriptional factors, PDX-1, NeuroD1, and MafA, causes differentiation of bone marrow mesenchymal stem cells into insulin-producing cells. Exp Diabetes Res 2012;2012:672013.

37 Thorens B: GLUT2, glucose sensing and glucose homeostasis. Diabetologia 2015;58:221-232.

38 Takamoto I, Kubota N, Nakaya K, Kumagai K, Hashimoto S, Kubota T, Inoue M, Kajiwara E, Katsuyama H, Obata A, Sakurai Y, Iwamoto M, Kitamura T, Ueki K, Kadowaki T: TCF7L2 in mouse pancreatic beta cells plays a crucial role in glucose homeostasis by regulating beta cell mass. Diabetologia 2014;57:542-553.

39 Shu L, Zien K, Gutjahr G, Oberholzer J, Pattou F, Kerr-Conte J, Maedler K: TCF7L2 promotes beta cell regeneration in human and mouse pancreas. Diabetologia 2012;55:3296-3307.

40 Rachdi L, Balcazar N, Osorio-Duque F, Elghazi L, Weiss A, Gould A, Chang-Chen KJ, Gambello MJ, BernalMizrachi E: Disruption of Tsc2 in pancreatic beta cells induces beta cell mass expansion and improved glucose tolerance in a TORC1-dependent manner. Proc Natl Acad Sci U S A 2008;105:9250-9255. 